20 Ward DJ. Fatal hypernatraemia after a saline emetic. Br Med F 1963;ii :432. 21 O'Driscoll BJ. Allergy to griseofulvin. Br Med $\mathcal{f} 1963$;ii:503.

${ }^{22}$ Prout BJ, Edwards EA. Agranulocytosis during administration of "Atromid." Br Med F 1963;ii:543-4.

${ }^{23}$ Law RR, Law R. Abortion after gammaglobulin. Br Med f 1963;ii:747.

${ }^{24}$ Sargant W. Antidepressant drugs and liver damage. $\mathrm{Br}$ Med $\mathcal{F}$ 1963;ii:806.

${ }^{25}$ Ross EDT, Settle JAD, Telfer ABM. Oral neomycin : a possible anaesthetic hazard. Br Med F 1963;ii:1109-10.

${ }^{26}$ Baker H, Pegum JS. Amiphenazole and bronchitis. Br Med f 1963 ;ii : 1473.

${ }^{27}$ Boyce J, Fawcett JW, Noall EWP. Coronary thrombosis and Conovid. Lancet 1963;i:111.

${ }^{28}$ Humphries SV. Convulsant effect of penicillin on the cerebral cortex. Lancet 1963 ; : 115-6.

29 Norris TStM. Promethazine and drug-induced jaundice. Lancet 1963 ; : 394.

${ }^{30}$ Bass BH. Megaloblastic anaemia due to nitrofurantoin. Lancet 1963; : 530-1.

${ }^{31}$ Janigan DT. Cytoplasmic bodies in the adrenal cortex of patients treated with spironolactone. Lancet $1963 ; \mathrm{i}: 850-2$.

32.Dix VW, Tresidder GC. Collapse after use of lignocaine jelly for urethral anaesthesia. Lancet $1963 ; \mathrm{i}: 890$.

${ }^{33}$ Thompson GR, Booth CC. Peptic ulcer following rectal steroids. Lancet $1963 ; \mathrm{i}: 949$.

${ }^{34}$ Durand P, Borrone C, Scarabicchi S, Razzi A. Griseofulvin and porphyrin metabolism. Lancet $1963 ; \mathrm{i}: 1160$.

${ }^{35}$ Saxen L, Kassinen A, Saxen E. Peritoneal foreign body reaction caused by condom emulsion. Lancet 1963 ; :1295-6.

${ }^{36}$ Gault JE. Agranulocytosis due to amitriptyline. Lancet $1963 ; \mathrm{ii}: 44-5$.

37 Crause J. Jaundice associated with haloperidol. Lancet $1963 ;$ ii :890-1.

${ }^{38}$ Barrett PVD, Thier SO. Meningitis and pancreatitis associated with sulfamethizole. N Engl f Med 1963;268:36-7.

${ }^{39}$ Fletcher GF. Hypotensive reactions after small doses of reserpine given parenterally. $N$ Engl 7 Med 1963;268:309-10.

40 Satuline LR. More on chlorthalidone. N Engl f Med 1963;268:390.

41 Pittman JG. Water intoxication due to oxytocin. N Engl $\mathcal{Y}$ Med 1963 ;268 481-2.

42 Hollander CS, Garcia AM, Sturgis SH, Selenkow HA. Effect of an ovulatory suppressant on the serum protein bound iodine and the redcell uptake of radioactive tri-iodothyronine. $N$ Engl F Med 1963;269: $501-4$
${ }^{13}$ Montgomery JR. Hemolytic reaction after novobiocin therapy. $N$ Engl f Med 1963;269:966.

44 Auerbach S, Mainwaring R, Schwarz F. Renal and ureteral damage following clinical use of Renacidin. FAMA 1963;183:61-3.

45 Frimpter GW, Timpanelli AE, Eisenmenger WJ, Stein HS, Ehrlich LI Reversible "Fanconi syndrome" caused by degraded tetracycline. $\mathcal{F} A M A$ 1963;184:111-3.

${ }^{46}$ Klein M. Agranulocytosis secondary to chlorthalidone therapy. $\mathcal{F} A M A$ 1963;184:310-1.

47 Gelfand HM. Oral vaccine; associated paralytic poliomyelitis, 1962. FAMA 1963;184:948-56.

${ }^{48}$ Shwayder AJ. Polyvalent influenza vaccine. FAMA 1963;185:148.

${ }^{49}$ Kirschenbaum MB. Psoriasis following administration of antimalarial drugs. F $A M A$ 1963;185:1044.

${ }^{50}$ Edwards TS. Transient myopia due to tetracycline. $\mathcal{F} A M A 1963 ; 186: 69-70$

${ }^{1}$ Mark HH. Psychotogenic properties of cyclopentolate. $\mathcal{F} A M A 1963 ; 186$ : 430-1.

${ }^{52}$ Lubowe II. Oral contraceptive agents and hair loss. $\mathcal{F} A M A 1963 ; 186: 446$.

${ }^{53}$ Kaye BM. Oral contraceptives and depression. $7 A M A$ 1963;186:522.

${ }^{54}$ Cohen SB. Brain damage due to penicillin. $\mathcal{F} A M A$ 1963;186:899-902.

${ }^{55}$ Perry HM. Carcinoma and hydralazine toxicity in patients with malignant hypertension. F $A M A$ 1963;186:1020-2.

${ }^{56}$ Rawlins MD, Thompson JW. Pathogenesis of adverse drug reactions. In: Textbook of adverse drug reactions. Oxford: Oxford University Press, 1977.

${ }^{57}$ Holdsworth CD, Atkinson M, Goldie W. Hepatitis caused by the newer amino-oxidase inhibiting drugs. Lancet 1961 ;ii:621.

${ }^{58}$ Briggs JD, Kennedy AC, Goldberg A. Urinary white cell excretion after iron-sorbitol-citric acid. $\mathrm{Br} \mathrm{Med} \mathcal{F} 1963$;ii:323-4.

${ }^{59}$ Kramer SM, Leventhal JM, Hutchinson TA, Feinstein AR. An algorithm for the operational assessment of adverse drug reactions. $\mathcal{F A M A} 1979$ 242:623-32.

${ }^{60}$ Inman WHW, Vessey MP, Westerholm B, Engelund A. Thromboembolic disease and the steroidal content of oral contraceptives. $\mathrm{Br} \mathrm{Med} \mathcal{F} 1970$; ii :203-9.

61 Mann JI, Inman WHW, Thorogood M. Oral contraceptive use in older women and fatal myocardial infarction. $B r$ Med 7 1976;ii:445-7.

(Accepted 6 October 1981)

\title{
How good are articles on adverse drug reactions?
}

\author{
J VENULET, R BLATTNER, J VON BÜLOW， G C BERNEKER
}

\begin{abstract}
A study was carried out of the quality and completeness of articles on adverse drug reactions: $\mathbf{5 7 3 7}$ articles from 80 countries published between 1972 and 1979 were studied. Only $61 \%$ of the articles included information on the number of patients treated and the number with adverse drug reactions, yet these are essential for calculating the incidence of adverse reactions. In only $\mathbf{5 5} \%$ could the incidence of a particular adverse reaction be calculated.

Great importance is placed on articles on adverse reactions, particularly those that report on many patients. Authors and editors should ensure that articles include the following information: drug regimens,
\end{abstract}

Paper presented at the 11 th International Symposium on Clinical Pharmacology in Pisa, October 1981.

\footnotetext{
Medical Department, Drug Monitoring, Ciba-Geigy Ltd, 4002 Basle, Switzerland

J VENULET, MD, intensive surveillance

R BLATTNER, documentation and retrieval

$J$ voN BULLOW, PHD, data input

G C BERNEKER, MD, head, drug monitoing
}

numbers of patients treated, numbers of patients developing adverse reactions, and nature and incidence of adverse reactions.

\section{Introduction}

Published articles on adverse drug reactions are considered to be important, particularly for regulatory agencies and drug companies, as both have to rely heavily on worldwide experience by independent investigators in "daily life." It is important to know not only what adverse reactions occur but how often they occur, and this cannot be determined from individual case reports. Studies of large groups of patients are therefore especially important in providing quantitative information. But how good are articles at giving information on adverse drug reactions?

One review of 23 papers on adverse drug reactions published in a reputable medical journal showed serious shortcomings in most of them: in 14 articles the number of patients affected by particular symptoms was missing, and nine articles contained no information on dosage or duration of treatment. ${ }^{1}$ Similar inadequacies were found in 1600 clinical trials submitted by drug companies to licensing authorities ${ }^{2}$ : in $80 \%$ of the trials adverse reactions were referred to, but in only $44 \%$ was the number of different types of adverse reactions given and in only $13 \%$ was 
the incidence of adverse reactions given. Other authors have confirmed these inadequacies..$^{3-5}$

To study further the quality of articles reporting adverse drug reactions we looked at articles that related to Ciba-Geigy products. As these products are used in all branches of medicine all over the world articles relating to them are likely to be representative of all articles on adverse drug reactions.

\section{Methods}

We classified articles on adverse drug reactions into three types: reports on not more than five patients; review articles of many authors' experience; and articles on authors' own experience with many patients. The third type are particularly interesting as they give some idea of the incidence of adverse drug reactions. We consider here only this third type. There were 5737 such articles from 80 countries published between 1972 and 1979. They included articles ranging from those relating to formal clinical trials to unsolicited accounts of experience with treatment.

Microfiches of all publications are kept in our files, but some information is extracted from them and stored in computer files. The following is among the information stored in the computer: name of Ciba-Geigy drug (or of its generic equivalent); galenic form (reported or deduced); daily dose (or range thereof); duration of treatment (or range thereof); names of other drugs given at the same time; number of patients treated; patients' ages (or range thereof); reason for using the drug; number of patients with adverse reactions; list of adverse reactions seen; number of adverse reactions; name of author and country of origin of publication; publication's references; internal referee's assessment of usefulness made at time of entering the paper into the computer.

We analysed these data to determine how many of the articles contained particular types of information.

\section{Results}

Countries where 100 or more publications originated during 1972-9 were the USA (828 publications), France (771), Great Britain (694), the German Federal Republic (459), Italy (343), Japan (313), Switzerland (257), Sweden (234), Spain (134), Brazil (127), Austria (110), Finland (107), Denmark (102), and India (100). Table I shows the type of information contained in the $\mathbf{5 7 3 7}$ articles studied. Only $19 \%$ of the articles (column L) contained information on the number of patients treated, the number of patients who had adverse drug reactions, the number of adverse drug reactions, the age of the patients, the dose of drug used, the duration of treatment, and the galenic form of the drug. Only $61 \%$ of the articles (column D) included information on the number of patients treated and the number with adverse drug reactions, yet these are essential for calculating the incidence of adverse reactions. In only $55 \%$ was there sufficient information for the incidence of particular adverse reactions to be calculated (column G). Furthermore, a comparison of the information contained in articles published from 1972 to 1975 with those published from 1975 to 1979 showed no significant change.

Table II shows the type of information contained in articles from countries where more than 200 such articles originated. There were considerable variations, and articles from Japan, France, and Italy seemed to be the most complete.

Table III shows the type of information contained in articles from particular journals. In general, journals particularly devoted to therapeutic research $(9,10,11,14,18,19,29,30)$ tended to publish fairly complete papers. A group of more general medical journals $(1,2,4,5,17,20,21)$, however, some of them from Third World countries, also published papers with remarkably complete data.

We also looked indirectly at whether the specialty of the author affected the type of information contained in the articles. We did this by looking at articles on drugs used mainly in particular specialties: diclofenac, used mainly in rheumatology; maprotiline, used mainly in psychiatry; and oxprenolol, used mainly in cardiology. No significant differences emerged.

\section{Discussion}

Our results show that many articles on large numbers of patients treated with a particular drug and containing information on adverse drug reactions lack important data. We think that most researchers would have basic information on the numbers of patients treated, the numbers who had adverse drug reactions, the number of adverse reactions, the age of the patients, the dose of the drug, the duration of treatment, and the galenic form of the drug, yet only $19 \%$ of the articles contained all this information. Nor could we find any evidence that things are improving. Our results also show that this is a problem in all countries where large numbers of studies are undertaken, and in most international journals. Some journals are better than others, but whether this reflects the kind of papers received or the editorial policy we cannot say. We also have circumstantial evidence that no one specialty is better than another.

Do these findings matter? Yes, they do, because published

TABLE I-Availability of relevant data in 5737 medical publications (1972-9)

\begin{tabular}{|c|c|c|c|c|c|c|c|c|c|c|c|c|}
\hline Type of information: & $\mathbf{A}$ & $\mathbf{B}$ & C & $\mathbf{D}$ & $\mathbf{E}$ & $\mathbf{F}$ & G & $\mathbf{H}$ & I & $\mathbf{J}$ & $\mathbf{K}$ & $\mathbf{L}$ \\
\hline $\begin{array}{l}\text { No of patients treated } \\
\text { No of patients with adverse reaction } \\
\text { No of adverse reactions } \\
\text { Any information on age } \\
\text { Any information on dose } \\
\text { Any information on duration of treatment } \\
\text { Any information on galenic form }\end{array}$ & + & + & + & + & $\begin{array}{l}+ \\
+\end{array}$ & $\stackrel{+}{+}$ & $\begin{array}{l}+ \\
+ \\
+\end{array}$ & $\begin{array}{l}+ \\
+ \\
+\end{array}$ & $\begin{array}{l}+ \\
+ \\
+\end{array}$ & $\begin{array}{l}+ \\
+ \\
+\end{array}$ & $\stackrel{+}{+}$ & $\begin{array}{l}+ \\
+ \\
+ \\
+ \\
+ \\
+ \\
+\end{array}$ \\
\hline
\end{tabular}

TABLE II-Availability of relevant data in medical publications originating from selected countries (1972-9). (Figures in lower part of table are numbers (\%) of publications)

\begin{tabular}{|c|c|c|c|c|c|c|c|c|c|c|c|c|}
\hline Type of information & $\mathbf{A}$ & B & C & D & $\mathbf{E}$ & $\mathbf{F}$ & G & $\mathbf{H}$ & $\mathbf{I}$ & $\mathbf{J}$ & $\mathbf{K}$ & $\mathbf{L}$ \\
\hline $\begin{array}{l}\text { No of patients treated } \\
\text { No of patients with adverse reaction } \\
\text { No of adverse reactions } \\
\text { Any information on age } \\
\text { Any information on dose } \\
\text { Any information on duration of treatment } \\
\text { Any information on galenic form }\end{array}$ & + & + & + & + & $\begin{array}{l}+ \\
+\end{array}$ & $\stackrel{+}{+}$ & $\begin{array}{l}+ \\
+ \\
+\end{array}$ & $\begin{array}{r}+ \\
+ \\
+\end{array}$ & $\begin{array}{l}+ \\
+ \\
+\end{array}$ & $\begin{array}{l}+ \\
+ \\
+\end{array}$ & $\begin{array}{l}+ \\
+ \\
+\end{array}$ & $\begin{array}{l}+ \\
+ \\
+ \\
+ \\
+ \\
+ \\
+\end{array}$ \\
\hline $\begin{array}{l}\text { Switzerland }(n=257) \\
\text { German Federal Republic }(n=459) \\
\text { France }(n=771) \\
\text { Great Britain }(n=694) \\
\text { Sweden }(n=234) \\
\text { USA }(n=828) \\
\text { Italy }(n=343) \\
\text { Japan }(n=313)\end{array}$ & $\begin{array}{l}221(86) \\
394(86) \\
713(92) \\
631(91) \\
197(84) \\
690(83) \\
317(92) \\
293(94)\end{array}$ & $\begin{array}{l}159(62) \\
305(66) \\
538(70) \\
403(58) \\
167(71) \\
503(61) \\
235(69) \\
250(80)\end{array}$ & $\begin{array}{l}163(63) \\
292(64) \\
559(73) \\
427(62) \\
162(69) \\
514(62) \\
243(71) \\
249(80)\end{array}$ & $\begin{array}{l}137(53) \\
276(60) \\
509(66) \\
379(55) \\
147(63) \\
446(54) \\
217(63) \\
245(78)\end{array}$ & $\begin{array}{l}142(55) \\
261(57) \\
529(69) \\
400(58) \\
140(60) \\
448(54) \\
228(66) \\
242(77)\end{array}$ & $\begin{array}{l}141(55) \\
268(58) \\
493(64) \\
344(50) \\
155(66) \\
449(54) \\
221(64) \\
234(75)\end{array}$ & $\begin{array}{l}120(47) \\
239(52) \\
466(60) \\
322(46) \\
137(59) \\
394(48) \\
206(60) \\
230(73)\end{array}$ & $\begin{array}{r}61(24) \\
115(25) \\
311(40) \\
163(23) \\
69(29) \\
221(27) \\
131(38) \\
177(57)\end{array}$ & $\begin{array}{r}71(28) \\
181(39) \\
380(49) \\
280(40) \\
90(38) \\
297(36) \\
165(48) \\
218(70)\end{array}$ & $\begin{array}{r}75(29) \\
162(35) \\
338(44) \\
223(32) \\
79(34) \\
267(32) \\
159(46) \\
190(61)\end{array}$ & $\begin{array}{l}137(53) \\
276(60) \\
509(66) \\
379(55) \\
147(63) \\
446(54) \\
217(63) \\
245(78)\end{array}$ & $\begin{array}{r}27(11) \\
56(12) \\
177(23) \\
95(14) \\
41(18) \\
113(14) \\
79(23) \\
146(47)\end{array}$ \\
\hline
\end{tabular}


TABLE III-Availability of relevant data in publications from selected medical journals (1972-9). (Figures in lower part of table are numbers (\%) of publications)

\begin{tabular}{|c|c|c|c|c|c|c|c|c|c|c|c|c|}
\hline Type of information & $\mathbf{A}$ & B & C & D & $\mathbf{E}$ & $\mathbf{F}$ & G & $\mathbf{H}$ & I & $\mathrm{J}$ & $\mathbf{K}$ & $\mathbf{L}$ \\
\hline $\begin{array}{l}\text { No of patients treated } \\
\text { No of patients with adverse reaction } \\
\text { No of adverse reactions } \\
\text { Any information on age } \\
\text { Any information on dose } \\
\text { Any information on duration } \\
\text { Any information on galenic form }\end{array}$ & + & + & + & $\stackrel{+}{+}$ & $\begin{array}{l}+ \\
+\end{array}$ & + & $\begin{array}{l}+ \\
+ \\
+\end{array}$ & $\begin{array}{l}+ \\
+ \\
+\end{array}$ & $\begin{array}{l}+ \\
+ \\
+\end{array}$ & $\begin{array}{l}+ \\
+ \\
+\end{array}$ & $\begin{array}{l}+ \\
+ \\
+\end{array}$ & $\begin{array}{l}+ \\
+ \\
+ \\
+ \\
+ \\
+ \\
+\end{array}$ \\
\hline $\begin{array}{l}\text { Australia: } \\
\text { 1 Medical fournal of Australia }(\mathrm{n}=34) \\
\text { Brazil: }\end{array}$ & $29(85)$ & $20(59)$ & $24(71)$ & $18(53)$ & $21(62)$ & $19(56)$ & $17(50)$ & $12(35)$ & $15(44)$ & $12(35)$ & $18(53)$ & $9(26)$ \\
\hline $\begin{array}{l}\text { Brazil: Folha Médica }(n=48) \\
\text { Denmark: }\end{array}$ & $48(100)$ & $40(83)$ & $41(85)$ & $40(83)$ & $41(85)$ & $37(77)$ & $37(77)$ & $29(60)$ & $31(65)$ & $37(77)$ & $40(83)$ & $18(38)$ \\
\hline 3 Ugeskrift for Laeger $(n=24)$ & $20(83)$ & $17(71)$ & $21(88)$ & $14(58)$ & $17(71)$ & $17(71)$ & $14(58)$ & $4(17)$ & $9(38)$ & $4(17)$ & $14(58)$ & 0 \\
\hline 4 Ain Shams Medical fournal $(=20)$ & $20(100)$ & $14(70)$ & $15(75)$ & $14(70)$ & $15(75)$ & $13(65)$ & $13(65)$ & $8(40)$ & $13(65)$ & $13(65)$ & $14(70)$ & $6(30)$ \\
\hline $\begin{array}{l}\text { France: } \\
7 \text { Gazette Médicale de France }(\mathrm{n}=37) \\
6 \text { Nouvelle Presse Médicale }(\mathrm{n}=15)\end{array}$ & $\begin{array}{l}36(97) \\
14(93)\end{array}$ & $\begin{array}{l}27(73) \\
10(67)\end{array}$ & $\begin{array}{l}29(78) \\
11(73)\end{array}$ & $\begin{array}{r}27(73) \\
9(60)\end{array}$ & $\begin{array}{l}29(78) \\
10(67)\end{array}$ & $\begin{array}{l}27(73) \\
10(67)\end{array}$ & $\begin{array}{r}27(73) \\
9(60)\end{array}$ & $\begin{array}{r}15(41) \\
5(33)\end{array}$ & $\begin{array}{r}21(57) \\
9(60)\end{array}$ & $\begin{array}{r}20(54) \\
6(40)\end{array}$ & $\begin{array}{r}27(73) \\
9(60)\end{array}$ & $\begin{aligned} 11(30) \\
3(20)\end{aligned}$ \\
\hline $\begin{array}{l}\text { German Federal Republic: } \\
7 \text { Deutsche Medizinische Wochenschrift } \\
(\mathrm{n}=18) \\
8 \text { Therapiewoche }(\mathrm{n}=48) \\
9 \text { European fournal of Clinical }\end{array}$ & $\begin{array}{l}15(83) \\
44(92)\end{array}$ & $\begin{array}{l}14(78) \\
37(77)\end{array}$ & $\begin{array}{l}14(78) \\
27(56)\end{array}$ & $\begin{array}{l}13(72) \\
35(73)\end{array}$ & $\begin{array}{l}13(72) \\
25(52)\end{array}$ & $\begin{array}{l}14(78) \\
26(54)\end{array}$ & $\begin{array}{l}13(72) \\
24(50)\end{array}$ & $\begin{array}{r}4(22) \\
16(33)\end{array}$ & $\begin{array}{r}8(44) \\
31(65)\end{array}$ & $\begin{array}{r}4(22) \\
29(60)\end{array}$ & $\begin{array}{l}13(72) \\
35(73)\end{array}$ & $\begin{array}{l}2(11) \\
8(17)\end{array}$ \\
\hline $\begin{array}{l}\text { Pharmacology }(\mathrm{n}=31) \\
10 \text { International fournal of Clinical }\end{array}$ & $30(97)$ & $20(65)$ & $18(58)$ & $19(61)$ & $17(55)$ & $17(55)$ & $16(52)$ & $13(42)$ & $16(52)$ & $11(35)$ & $19(61)$ & $8(26)$ \\
\hline $\begin{array}{l}\text { Pharmacology and Biopharmacy }(\mathrm{n}=8) \\
11 \text { Arzneimittel-Forschung }(\mathrm{n}=27) \\
12 \text { Medizinische Welt }(\mathrm{n}=23)\end{array}$ & $\begin{array}{l}8(100) \\
27(100) \\
22(96)\end{array}$ & $\begin{array}{l}7(88) \\
17(63) \\
16(70)\end{array}$ & $\begin{array}{l}8(100) \\
16(59) \\
17(74)\end{array}$ & $\begin{array}{l}7(88) \\
17(63) \\
16(70)\end{array}$ & $\begin{array}{l}8(100) \\
16(59) \\
17(74)\end{array}$ & $\begin{array}{l}7(88) \\
16(59) \\
14(61)\end{array}$ & $\begin{array}{r}7(88) \\
16(59) \\
14(61)\end{array}$ & $\begin{array}{r}5(63) \\
11(41) \\
6(26)\end{array}$ & $\begin{array}{r}7(88) \\
16(59) \\
10(43)\end{array}$ & $\begin{array}{r}5(63) \\
14(52) \\
9(39)\end{array}$ & $\begin{array}{r}7(88) \\
17(63) \\
16(70)\end{array}$ & $\begin{array}{l}3(38) \\
10(37) \\
2(9)\end{array}$ \\
\hline $\begin{array}{l}\text { Great Britain: } \\
13 \text { British Medical Fournal }(\mathrm{n}=59) \\
14 \text { British fournal of Clinical }\end{array}$ & $49(83)$ & $40(68)$ & $43(73)$ & $34(58)$ & $36(61)$ & $34(58)$ & $29(49)$ & $11(19)$ & $21(36)$ & $15(25)$ & $34(58)$ & $6(10)$ \\
\hline $\begin{array}{l}\text { Pharmacology }(\mathrm{n}=36) \\
\text { Pournal of International Medical }\end{array}$ & $36(100)$ & $24(67)$ & $25(69)$ & $24(67)$ & $25(69)$ & $21(58)$ & $21(58)$ & $16(44)$ & $19(53)$ & $19(53)$ & $24(67)$ & $11(31)$ \\
\hline $\begin{array}{l}\text { Research }(n=99) \\
16 \text { Lancet }(n=49) \\
\text { Ity: }\end{array}$ & $\begin{array}{l}93(94) \\
44(90)\end{array}$ & $\begin{array}{l}52(53) \\
43(88)\end{array}$ & $\begin{array}{l}53(54) \\
39(80)\end{array}$ & $\begin{array}{l}51(52) \\
38(78)\end{array}$ & $\begin{array}{l}51(52) \\
35(71)\end{array}$ & $\begin{array}{l}40(40) \\
38(78)\end{array}$ & $\begin{array}{l}39(39) \\
34(69)\end{array}$ & $\begin{array}{l}36(36) \\
16(33)\end{array}$ & $\begin{array}{l}46(47) \\
23(47)\end{array}$ & $\begin{array}{l}39(39) \\
19(39)\end{array}$ & $\begin{array}{l}51(52) \\
38(78)\end{array}$ & $\begin{array}{r}21(21) \\
9(18)\end{array}$ \\
\hline $\begin{array}{l}17 \text { Minerva Medica }(\mathrm{n}=24) \\
18 \text { Clinica Terapeutica }(\mathrm{n}=27)\end{array}$ & $\begin{array}{l}22(92) \\
24(89)\end{array}$ & $\begin{array}{l}17(71) \\
19(70)\end{array}$ & $\begin{array}{l}17(71) \\
18(67)\end{array}$ & $\begin{array}{l}15(63) \\
17(63)\end{array}$ & $\begin{array}{l}15(63) \\
18(67)\end{array}$ & $\begin{array}{l}16(67) \\
17(63)\end{array}$ & $\begin{array}{l}14(58) \\
17(63)\end{array}$ & $\begin{array}{l}11(46) \\
10(37)\end{array}$ & $\begin{array}{l}12(50) \\
14(52)\end{array}$ & $\begin{array}{l}13(54) \\
15(56)\end{array}$ & $\begin{array}{l}15(63) \\
17(63)\end{array}$ & $\begin{array}{l}7(29) \\
8(30)\end{array}$ \\
\hline $\begin{array}{l}\text { Japan: } \\
19 \text { Chemotherapy }(\mathrm{n}=139) \\
20 \text { Shinryo To Shinyaku }(\mathrm{n}=22)\end{array}$ & $\begin{array}{l}135(97) \\
22(100)\end{array}$ & $\begin{array}{r}122(88) \\
21(95)\end{array}$ & $\begin{array}{r}123(88) \\
17(77)\end{array}$ & $\begin{array}{r}120(86) \\
21(95)\end{array}$ & $\begin{array}{r}121(87) \\
17(77)\end{array}$ & $\begin{array}{r}121(87) \\
17(77)\end{array}$ & $\begin{array}{r}119(86) \\
17(77)\end{array}$ & $\begin{array}{r}101(73) \\
16(73)\end{array}$ & $\begin{array}{r}111(80) \\
21(95)\end{array}$ & $\begin{array}{r}103(74) \\
20(91)\end{array}$ & $\begin{array}{r}120(86) \\
21(95)\end{array}$ & $\begin{array}{l}88(63) \\
12(55)\end{array}$ \\
\hline $\begin{array}{l}\text { Mexico: } \\
21 \text { Prensa Medica Mexicana }(\mathrm{n}=12)\end{array}$ & $12(100)$ & $10(83)$ & $9(75)$ & $10(83)$ & $9(75)$ & $9(75)$ & $9(75)$ & $9(75)$ & $8(67)$ & $5(42)$ & $10(83)$ & $4(33)$ \\
\hline $\begin{array}{l}\text { New Zealand: } \\
22 \text { New Zealand Medical fournal }(\mathrm{n}=29) \\
\text { Norway: }\end{array}$ & $22(76)$ & $20(69)$ & $19(66)$ & $17(59)$ & $17(59)$ & $17(59)$ & $15(52)$ & $3(10)$ & $5(17)$ & $4(14)$ & $17(59)$ & $2(7)$ \\
\hline $\begin{array}{l}\text { Norway: } \\
23 \text { Tidsskrift for den Norske } \\
\text { Laegeforening }(\mathrm{n}=13)\end{array}$ & $10(77)$ & $7(54)$ & $10(77)$ & $6(46)$ & $7(54)$ & $7(54)$ & $6(46)$ & $2(15)$ & $3(23)$ & $2(15)$ & $6(46)$ & $2(15)$ \\
\hline $\begin{array}{l}\text { South Africa: } \\
24 \text { South African Medical fournal }(n=31)\end{array}$ & $30(97)$ & $20(65)$ & $22(71)$ & $20(65)$ & $22(71)$ & $18(58)$ & $18(58)$ & $7(23)$ & $16(52)$ & $11(35)$ & $20(65)$ & $4(13)$ \\
\hline $\begin{array}{l}\text { Sweden: } \\
25 \text { Acta Medica Scandinavica }(\mathrm{n}=43) \\
26 \text { Läkartidningen }(\mathrm{n}=26)\end{array}$ & $\begin{array}{l}32(74) \\
17(65)\end{array}$ & $\begin{array}{l}31(72) \\
18(69)\end{array}$ & $\begin{array}{l}29(67) \\
19(73)\end{array}$ & $\begin{array}{l}22(51) \\
13(50)\end{array}$ & $\begin{array}{l}21(49) \\
13(50)\end{array}$ & $\begin{array}{l}29(67) \\
18(69)\end{array}$ & $\begin{array}{l}21(49) \\
13(50)\end{array}$ & $\begin{array}{c}13(30) \\
2(8)\end{array}$ & $\begin{array}{r}13(30) \\
3(12)\end{array}$ & $\begin{array}{l}8(19) \\
3(12)\end{array}$ & $\begin{array}{l}22(51) \\
13(50)\end{array}$ & $\begin{array}{l}5(12) \\
1(4)\end{array}$ \\
\hline $\begin{array}{l}\text { Switzerland: } \\
27 \text { Schweizerische Medizinische } \\
\text { Wochenschrift }(\mathrm{n}=31) \\
28 \text { Schweizer Rundschau }(\mathrm{n}=22) \\
\end{array}$ & $\begin{array}{l}26(84) \\
20(91)\end{array}$ & $\begin{array}{l}22(71) \\
12(55)\end{array}$ & $\begin{array}{l}19(61) \\
12(55)\end{array}$ & $\begin{array}{l}18(58) \\
10(45)\end{array}$ & $\begin{array}{l}15(48) \\
10(45)\end{array}$ & $\begin{array}{l}18(58) \\
10(45)\end{array}$ & $\begin{array}{r}14(45) \\
8(36)\end{array}$ & $\begin{array}{l}8(26) \\
6(27)\end{array}$ & $\begin{array}{l}7(23) \\
8(36)\end{array}$ & $\begin{array}{l}9(29) \\
7(32)\end{array}$ & $\begin{array}{l}18(58) \\
10(45)\end{array}$ & $\begin{array}{l}4(13) \\
3(14)\end{array}$ \\
\hline $\begin{array}{l}29 \text { Clinical Pharmacology and } \\
\text { Therapeutics }(\mathrm{n}=33) \\
30 \text { Current Therapeutic Research }(\mathrm{n}=68) \\
31 \text { fournal of the American Medical }\end{array}$ & $\begin{array}{l}29(88) \\
65(96)\end{array}$ & $\begin{array}{l}16(48) \\
37(54)\end{array}$ & $\begin{array}{l}19(58) \\
36(53)\end{array}$ & $\begin{array}{l}14(42) \\
37(54)\end{array}$ & $\begin{array}{l}17(52) \\
36(53)\end{array}$ & $\begin{array}{l}16(48) \\
29(43)\end{array}$ & $\begin{array}{l}14(42) \\
.29(43)\end{array}$ & $\begin{array}{r}7(21) \\
32(47)\end{array}$ & $\begin{array}{l}13(39) \\
36(53)\end{array}$ & $\begin{array}{l}12(36) \\
34(50)\end{array}$ & $\begin{array}{l}14(42) \\
37(54)\end{array}$ & $\begin{array}{r}7(21) \\
22(32)\end{array}$ \\
\hline Association $(\mathrm{n}=19)$ & $17(89)$ & $14(74)$ & $14(74)$ & $12(63)$ & $12(63)$ & $14(74)$ & $12(63)$ & $8(42)$ & $6(32)$ & $7(37)$ & $12(63)$ & $4(21)$ \\
\hline
\end{tabular}

articles, particularly those that report on large numbers of patients, are a unique source of data. They are essential for assessing the importance and incidence of adverse reactions, which in its turn is obviously essential for rational prescribing. It is striking that while so much importance is placed on published articles the quality of so many is so poor.

There is obviously a need to improve the quality of articles containing information on adverse drug reactions, but how can this be done? The responsibility clearly lies with both authors and editors. One important way in which authors can help is by not publishing information in more than one journal without acknowledging that it has been published elsewhere. In our study we came across many examples of authors doing exactly this. This is an important problem that others have recognised. ${ }^{6}$ ? Authors should always include information on drug regimens, numbers of patients treated, numbers of patients developing adverse drug reactions, and the nature and incidence of the reactions, and editors should insist that this minimum information is included. Lock has written on the responsibility of the medical press, ${ }^{8}$ and we agree with Altman that, "The ultimate responsibility for the general standard of published research rests with the medical journals. Perhaps unwillingly the journals have the role of guardian of quality." " But the authors should not make this task too difficult.

\section{References}

${ }^{1}$ Laganière S, Biron P. Clinical trials: incomplete reporting of side effects. Current Therapeutic Research $1979 ; 25: 743-6$.

2 Hemminki E. Study of information submitted by drug companies to licensing authorities. $\mathrm{Br}$ Med 7 1980;280:833-6.

${ }^{3}$ Hibberd PL, Meadows AJ. Information contained in clinical trial reports. Fournal of Information Sciences 1980;2:165-8.

4 Windsor DA. Adverse reactions literature: a bibliometric analysis. Methods of Inf Med 1977;16:52-4.

${ }^{5}$ Begaud B, Pere JC, Dangoumau J. Mise en oeuvre d'un critère: la bibliographie. Therapie $1981 ; 36: 233-6$

${ }^{6}$ Broad WJ. The publishing game: getting more for less. Science $1981 ; 211$. 1137-9.

${ }^{7}$ Geiseler PJ. Unnecessary duplication of publication. $N$ Engl f Med 1980; 302:1209-16.

${ }^{8}$ Lock SP. Responsibility of medical press. In : Inman WHW, ed. Monitoring for drug safety. Lancaster: MTP Press, 1980:637-46.

- Altman DG. Improving the cuality of statistics in medical journals. Br Med F 1981 ;282:44-7.

(Accepted 26 November 1981) 